\title{
MINYAK ATSIRI DARI Toona sinensis DAN UJI AKTIVITAS INSEKTISIDA
}

\author{
Adlis Santoni ${ }^{1}$, Hazli Nurdin ${ }^{1}$, Yunazar Manjang' ${ }^{1}$ Sjamsul A. Achmad ${ }^{2}$ \\ ${ }^{1}$ Jurusan Kimia FMIPA Universitas Andalas, Kampus Limau Manis, Padang \\ ${ }^{2}$ Program Studi Kimia Institut Teknologi Bandung \\ email: adlis_1962@yahoo.com
}

\begin{abstract}
Volatile components from leafs of Toona sinensis (Meliaceae) were isolated by distillation watervapour method and analyzed using GC/MS. Forty-eight component were identified, and eight major components are Germacrene- $\mathrm{D}$, Germacrene-B, $\alpha$-Terpinene, $\alpha$-Humulene, $\beta$-Caryophyllene, $\alpha$-Elemene, Bicyclogermacrene and $\alpha$-copaene. Insect activity of the essential oil against Crosidolomia pavonana were tested. The activity of the essential oil with concentration $25 \%$ (mortality $73.3 \%$ ), concentration 50\% (mortality $83.3 \%$ ) and concentration $75 \%$ (mortality $90 \%$ ).
\end{abstract}

Keywords : Toona sinensis (Meliaceae), essential oil, Crosidolomia pavonana, and mortality.

\section{DAFTAR PUSTAKA}

1. J. T. Arnason, S. Mackinnon, A. Durst, B. J. R. Philogene, Hasbun, P. Sanchez, L. Poveda, L. San Roman, M. B. Isman, C. Satasook, G. H. N Towers, P. Wiriyachitra, and JLMC, Laughlin, Insecticides in tropical plants with non-neurotoxic modes of action, Phytochemical Potential of Tropical Plants, 107-151, (1993).

2. D. J. Mabberley, C. M. Pannel \& A. M. Sing, Flora Malesiana, Series ISpermathophyta: Flowering plants, Leiden University, 12: 1-20, 1995

3. SAS Institut, SAS/STAT User's Guide, North Carolina, SAS Institut Inc., Version 6, fourth ed., 2, 1990.

4. A. J. Prakash, Rao, Botanical pesticides in agriculture, CRC Press, New York, London, 1997, 461.

5. R. Nishida et al., Journal of Chemical Ecology, 26: 87, (2000).

6. T. Rostelien, A. K Borg-Karlson, The Plant Sesquiterpene Germacrene D Specifically Activates a major type of Antennal Receptor Neuron of the Tobacco Budworm Moth Heliothis virescens, Chem. Sense, 25: 141-148, (2000).
7. M. G. Chisholm, M. A. Wilson, et al., Flavour and Fragrance Journal. 18(2): 106-115, (2003).

J. Lawrence, Porter, "Flavans and proanthocyanidins", In The Flavanoids: Advances in Research Since 1986 (J.B. Harborne, Ed.), Chapman \& Hall, London, 23$55,1994$.

D. Ngnokam, G. Massiot, J. M. Nuzillard and E. Tsamo, '“(+)-7',7'-Dimethyl-5-hydroxy2R,3S-Trans-Pubeschin From Entandrophragma cylindrum, Phytochemistry, 37: 529-531, (1994).

D. E. Champagne, M. B. Isman, Towers GHN, Insecticidal activity of phytochemicals and extracts of the Meliaceae, Di dalam: Arnason JT, Philogne BJR, Morand P, editor. Insecticides of plant origin, Washington DC: ACS, 1989, 95-109.

V. H. Kapadia et al., "Structure of mustakone and copaene". Tetrahedron Letters, 28: 1933, (1963).

1. 
